DISERTACIJE - DISSERTATIONS

\title{
MUZIČKI INSTRUMENTI U SREDNJOVJEKOVNOJ LIKOVNOJ UMJETNOSTI HRVATSKE
}

\author{
Musical Instruments in the Medieval Art in Croatia
}

\author{
Koraljka K o s
}

Prikazi glasbenih instrumentov v srednjeveški likovni umetnosti na Hrvatskem doslej še niso bili sistematično obdelani. Ti prikazi vsebujejo elemente, ki osvetljujejo hrvatsko glasbeno preteklost, razen tega pa so koristni kot vir za splošno organografijo instrumentov, $\mathrm{ki}$ je doslej pri preučevanju porekla in razvoja evropskega instrumentarija le redko uporabljala gradivo tega področja. V prvem delu razprave je izvedena organografska analiza instrumentov, ki so prikazani na srednjeveških likovnih spomenikih na Hrvatskem. Ob analizi konstrukcije in načina držanja posameznih instrumentov napravi avtor tudi primerjavo s sočasnimi prikazi teh instrumentov $\mathbf{v}$ evropski likovni umetnosti. Najzgodnejši prikazi instrumentov se pojavijo $\mathrm{v}$ hrvatski likovni umetnosti na področju dalmatinske romanske skulpture. Med temi izstopata viella in trioglata harfa na klopi kora $v$ splitski stolnici (13. stoletje). Med številnimi prikazi instrumentov na istrskih freskah se odlikujejo po preciznosti registriranja konstrukcije in izvajalne tehnike instrumenti v cerkvah sv. Antona v Žminju (konec 14. stoletja), sv. Martina in sv. Marije na Škriljinah v Bernu (1431 in 1474) ter sv. Jurija v Lovranu (1470-1479). Poleg prikazov lutenj in pihal oziroma trobil (dolge in kratke busine, rogovi, šalmaji, blokflavte, dude) najdemo na teh freskah tudi prikaze viell, portativov, psalterijev, organistrumov, harf in raznih tolkal (zvončki, triangl, timpani, boben, tamburin). Po nenavadnem načinu držanja izstopa viella, ki jo ima $\mathbf{v}$ rokah kralj David $\mathbf{v}$ cerkvi sv. Marije v Škriljinah v Bermu. Redkosti glede na čas in prostor preučevanja pa predstavljajo kolo z zvonci (Glockenrad), klavikord, klavičembalo in cimbal iz cerkve sv. Jurija v Lovranu. - V likovni umetnosti Dalmacije iz 15. in 16. stoletja odkrijemo figure dečkov-muzikantov kot karakteristični kiparski okrasni motiv arhitekture Dubrovnika, Korčule, Splita in Šibenika. Med temi so zuačilni realistični prikazi dečkov z dudami in običajna srednjeveška kombinacija senoročne« piščali in bobna na portalu sv. Mihaela v katedrali na Korčuli (15. stoletje). Realistična skupina muzikantov na podboju knežje palače v Dubrovniku (15. stoletje) muzicira na trobente in pozitiv. Harfa in portativ, na katera muzicirata dva angela na poliptihu Lovra Dobričevića na Dančah v Dubrovniku (okrog 1465) sta zelo podobna instrumentom na sliki Madonna in den Rosenhaag Stephana Lochnerja iz leta 1444. Precizno je registrirana izvajalna praksa pri instrumentih, ki jih igrajo angeli na poliptihu Dujma Vuškovića (okrog 1450) v Zadru. — Od maloštevilnih ohranjenih prikazov glasbenih instrumentov $v$ umetnosti znotraj Hrvatske je zanimiv portativ $v$ rokah sv. Cecilije na lesenem ootskem oltarju $v$ Remetincu v Hrvaškem Zagorju (okrog 1470), kjer se jasno vidi, kako štrlijo iz 
korpusa instrumenta tipke kot tanke ploščice. - Prikazi instrumentov na minia* turah $\mathbf{v}$ latinskih rokopisnih kodeksih, ki so shranjeni $\mathbf{v}$ zagrebški univerzitetni knjižnici in $\mathbf{v}$ dalmatinskih samostanskih bibliotekah, spremljajo splošni razvoj evropskega instrumentarija. Pogoste so upodobitve harfe, portativa, zvončkov, lutnje in psalterija. V 15. stoletju se zveča znatno raznolikost upodobljenih instrumentov in njihova diferenciacija $\mathbf{v}$ okviru posameznih skupin. Med najlepše upodobitve iz tega časa štejemo viello, ki jo igra kralj David v splitskem rokopisu Psalterium Romanum, in instrumente $\mathbf{v}$ zadrskem rokopisu Psalterium chori » $\mathbf{M}_{« \text {. }}$

Analizirane upodobitve muziciranja se ikonografsko vključujejo $\mathrm{v}$ zahodni in srednjeevropski okvir, in to ne glede na nekatere odklone od ustaljenih obrazcev in kljub svobodnejši interpretaciji religioznih tem. Tako se javljata portativ in trobenta na ljudskem prikazu Živega križa (Lindar, Istra, 1409) kot simbola Ecclesiae in Sinagoge. Sicer pa najdemo instrumente največkrat $v$ rokah angelov poleg Matere božje (istrske freske, poliptiha Dujma Vuškovića in Lovra Dobričevića), na prizorih Kristusovega rojstva, Epifanije (Beram, sv. Marija na Škriljinah) in Mrtvaškega plesa. V 15. stoletju odkrijemo angele z glasbili tudi na poljih gotskih mrežastih svodov kot udeležence hvalospeva osrednji figuri Kristusa. $\mathrm{V}$ posvetni tematiki je značilen žanrski lik muzikantov kakor tudi samostojno realistično muziciranje skupine puttov (Dubrovnik, knežja palača).

Obravnavano gradivo podkrepe podatki o instrumentalistih, ki so bili v srednjem veku na Hrvatskem, podatki o uporabi instrumentov $\mathbf{v}$ gledaliških predstavah in misterijih $\mathrm{v}$ Dubrovniku in na Hvaru, kakor tudi občasno omenjanje instrumentov $v$ literaturi tega obdobja. Na podlagi analize značilnih instrumentalnih grupacij so doseženi določeni sklepi o izvajalni praksi. Geografska razširjenost upodobitev posameznih instrumentov je ilustrirana $z$ zemljepisnimi kartami. Variante $\mathbf{v}$ upodobitvah harfe, psalterija in godal so prikazane z rishami profilov teh instrumentov. Posebno prilogo razprave tvori mapa s 120 posnetki likovnih del, na katerih so upodobljeni glasbeni instrumenti.

Obranjena dne 16. decembra 1967 na filozofski fakulteti univerze v Ljubljani.

The representation of musical instruments in Medieval Croatian art has not yet been systematically dealt with. It comprises elements which help elucidate the history of music. In addition it provides a valuable source material for a general organography of instruments, which has till now only seldom employed this material when dealing with the origin and development of European instruments. In the first part of the dissertation an organographical analysis of instruments represented in Medieval monuments in Croatia is carried out. In the analysis of the construction of and the way of holding individual instruments, the author also makes a comparison with the contemporary representation of these instruments in European art. The representations of instruments in Croatian art occur in Romanesque sculpture in Dalmatia. Among them a viella and a triangular harp carved on a choir bench in the thirteenth century cathedral of Split deserve special attention. Of numerous depictions of instruments in the frescoes in Istria, those in the churches of St. Anthony in Žminj (end of the 14th century), of St. Martin and St. Mary in Škriljine and Beram (1431 and 1474), and of St. George in Lovran (1470-1479) are most striking owing to the precise representation of 
the construction of the instruments and their method of playing. Besides the lute and wind and brass instruments - long and short busines, horns, shawms, flutes, bagpipes - we also find in these frescoes viellas, portative organs, psalteries, hurdygurdies, harps and various percussion instruments - jingles, the triangle, kettledrums, the drum, the tambourine. The viella held in the arms of King David in St. Mary's church in Škriljine and Beram demands our attention owing to the unusual holding position. The : glockenrad «, the harpsichord, the clavichord, and the dulcimer portrayed in the church of St.George in Lovran represent a rarity in the field and period with which this study has been concerned. In Dalmatian art of the 15 th and 16th century boys with wind instruments appear as a characteristic decorative sculpture motif in the architecture of Dubrovnik, Korčula, Split and Šibenik. Realistic representations of boys with bagpipes or with the usual Medieval combination of one-handed flute and drum on the portal of St. Michael in the Cathedral of Korčula (15th century) are especially important. In a detail of the portal of the Prince's Court in Dubrovnik a realistic group of instrumentalists play the trumpet and the positive organ. The harp and the portative organ played by two angels on the polyptych of Lovro Dobričević in Dubrovnik (c. 1465) are very similar to the instruments represented in the painting Madonna in dem Rosenhaag by Stephan Lochner, 1444. The method of performing on the instruments is depicted very precisley on the polyptych of Dujno Vušković (c. 1450) in Zadar which represents angel musicians. One interesting representation of a musical instrument of those few preserved in the art of inland Croatia is that of the portative organ placed in the hands of St. Cecily, depicted on the wooden Gothic altar at Remetinec in Zagorje (c. 1470), with the keys protruding from the instrument like thin metal plates. The depictions of instruments in the miniatures of the Latin manuscript codices which are housed in the National and University Library in Zagreb and in various monastery libraries in Dalmatia follow the general development of musical instruments in Europa. We often find portrayals of the harp, portative organ, bells, the lute and psaltery. The variety of instruments represented and their differentiation within individual groups considerably increased in the 15 th century. Among the finest dipictions are the viella played by king David in the manuscript Psalterium Romanum, and the instruments in the Zadar manuscript Psalterium Chori » $\mathbf{M}_{\ll}$.

Where iconography is concerned the analysed representations of music playing conform with the Central European pattern yet admitting occasional deviations from standard patterns and a freer interpretation of religious themes. So the organ portativ and the trumpet occur in the folk depiction of $»$ the Living Cross « as symbols of Ecclesia and Synagogue. The instruments are most often found in the hands of angels beside St. Mary (the frescoes of Istria, the polyptychs of Dujmo Vušković and Lovro Dobričević) in the scenes of the both of Christ and the Epiphany (Beram, St. Mary in Škriljine) and the Dance of Death. In the 15th century angels with instruments are to be found on Gothic reticular vaults as participants in songs of praise directed towards the central figure of Christ. Characteristic in secular themes is the genre figure of the piper and independent. realistic music-making 'groups of putti (Dubrovnik, the Prince's Court).

The material presented is corroborated by the data on the instrumentalists in Croatia in the Middle Ages, and the use of instruments in theatrical performances and mysteries in Dubrovnik and Hvar, and finally by occasional quotations 
concerning instruments in the literature of the period. Certain conclusions about the practice of performance are reached on the basis of the analysis of characteristic instrumental groupings. How the instruments are spread geographically is illustrated by maps. Variants in the depiction of harps, psalteries and string instruments are shown in the scheme of profiles on these instruments. A particular addition to the dissertation consists in a catalogue of 120 photographs of art works including representations of individual instruments.

Defended December 16, 1967, University of Ljubljana. 